Although it has been shown that smoking does not cause venous thrombosis, ${ }^{15}$ it is at first surprising to find that smokers with myocardial infarction are so much less likely to develop a leg vein thrombosis, and presumably pulmonary embolism, than smokers. As Doll ${ }^{16}$ has pointed out, however, patients with a removable cause for their disease do better when that cause is removed, and it is well established that smoking cigarettes is one of the causes of myocardial infarction. As we suggested earlier, patients who enter a coronary care unit with myocardial infarction may be drawn from two populations. One group may be intrinsically more susceptible to both arterial and venous thrombosis so will suffer myocardial infarction whether they smoke or not; the other group do not have this susceptibility to thrombosis but suffer a myocardial infarction because they smoke. This is undoubtedly an oversimplified account, but it is a reasonable explanation of why non-smokers are more likely to develop leg vein thrombosis after myocardial infarction.

We therefore conclude that low-dose heparin prophylaxis should be given routinely to all patients admitted to hospital with myocardial infarction who do not smoke ciagrettes.

We thank Mr A Bovington, who regularly carried out the leg scans, and the other physicians of Westminster Hospital for allowing us to include their patients in this study.

\section{References}

${ }^{1}$ Murray, T S, et al, Lancet, 1970, 2, 792

2 Maurer, B J, Wray, R, and Shillingford, J P, Lancet, 1971, 2, 1385.

${ }^{3}$ Nicolaides, A N, et al, British Medical fournal, 1971, 1, 432.

${ }^{4}$ Wood, P, Diseases of the Heart and Circulation, 3rd edn, p 856. London, Eyrie and Spottiswood, 1969.

${ }^{5}$ Hilden, T, et al, British Medical fournal, 1961, 2, 327.

${ }^{6}$ Hellerstein, H K, and Martin, J W, American Heart fournal, 1947, 33, 443.

${ }^{7}$ Handley, A J, Emerson, P A, and Fleming, P R, British Medical fournal, $1972,2,436$

${ }^{8}$ Marks, P, and Emerson, P A, British Medical fournal, 1974, 3, 232.

${ }^{9}$ Kakkar, V V, et al, Lancet, 1970, 1, 540.

10 Warlow, C, et al, Lancet, 1974, 1, 934.

11 Handley, A J, Lancet, 1972, 2, 623.

12 International Multicentre Trial, Lancet, 1975, 2, 45

13 Steffensen, K A, Acta Medica Scandinavica, 1969, 186, 519.

14 Handley, A J, and Teather, D, British Medical fournal, 1974, 3, 230.

15 Vessey, M, and Doll, R, British Medical fournal, 1969, 2, 651.

${ }^{16}$ Doll, R, British Medical fournal, 1974, 3, 466.

\title{
Wound sepsis after cholecystectomy: effect of incidental appendicectomy
}

\author{
A V POLLOCK, MARY EVANS
}

British Medical fournal, 1977, 1, 20-22

\section{Summary}

The records of a consecutive series of 224 patients were analysed to discover the effect of incidental appendicectomy on the wound sepsis rate after cholecystectomy. One hundred and five patients had had a cholecystectomy alone and 119 cholecystectomy with incidental appendicectomy. The incidence of wound sepsis in patients not given adequate antibiotic prophylaxis was significantly lower $(16 \cdot 1 \%)$ when cholecystectomy alone was carried out than when the appendix was removed as well (41.1\%).

\section{Introduction}

Many surgeons remove the normal appendix during a potentially contaminated laparotomy on the grounds that it is the only way to prevent later acute appendicitis. Hewitt et al calculated the risk of subsequently developing appendicitis and found a proprogressive decline from $16 \%$ at the age of $2 \frac{1}{2}$ years to $0.02 \%$ at the age of $87 \frac{1}{2}$ years.

The arguments against incidental appendicectomy in totally clean abdominal surgery are overwhelming, and few people would care to risk the contamination that might arise from removing the appendix during, for example, an abdominal aortic replacement. On the other hand, opinion is divided about

Scarborough Hospital, Scarborough, North Yorkshire A V POLLOCK, FRCS, consultant surgeon MARY EVANS, BA, research assistant the merits of incidental appendicectomy with operations such as cholecystectomy. The possibility of an increased liability to malignant disease after appendicectomy is still being debated.

Reports on the effects of incidental appendicectomy during abdominal operations-for example, by $\mathrm{Howie}^{2}$ - have been mainly concerned with the incidence of wound sepsis. In retrospective analyses of hospital case notes estimation of the sepsis rate is unreliable, and we have shown ${ }^{3}$ that nearly $40 \%$ of all cases of wound sepsis can be either so trivial or so late in onset that they are not mentioned.

This review was undertaken to compare the incidence of septic complications after cholecystectomy alone with those after cholecystectomy plus appendicectomy in patients who had been included in a series of prospective, controlled clinical trials of cephaloridine and other antibacterial substances as wound sepsis prophylactic agents. The effects of incidental appendicectomy on sepsis rates after gastric surgery will be presented in detail elsewhere. We found in these trials that the wound sepsis rates after removal of an inflamed appendix were $7.8 \%$ and $12.4 \%$ respectively in patients protected and not protected by cephaloridine, and $1.9 \%$ and $7.6 \%$ respectively aftẹr removal of a normal appendix.

\section{Patients and methods}

All patients under the care of one surgeon who were to have potentially contaminated abdominal operations were randomly allocated to receive either cephaloridine or no prophylaxis, ${ }^{45}$ gentamicin, ${ }^{6}$ povidone-iodine,${ }^{7}$ framycetin, ${ }^{8}$ ampicillin, ${ }^{3}$ or water irrigation (in progress). Details of each patient, including a double-blind assessment of wound sepsis for at least four weeks after operation, were entered on punch cards. We reviewed the cards, selecting patients who had had either a cholecystectomy alone or one with incidental appendicectomy. All other operations on the biliary tract, including choledochotomy, were excluded to ensure comparability within the 
series. The appendix was rarely removed with any other biliary operation.

Two hundred and twenty-seven cases (out of 347 biliary operations) were available for analysis, but three patients who died (one from septic shock three days after operation, the second on the ninth day from intraperitoneal haemorrhage, and the third from cardiac infarction on the 11th day) were not included in the assessment of wound sepsis.

In the early trials bacteriological investigation was confined to wound discharges, but later swabs were taken of the contents of hollow viscera and of subcutaneous tissues at the end of an operation. Our present practice is to transport a fragment of an incised organ and (at the end of each operation) of the subcutaneous tissue in Robertson's meat medium from the operating theatre to the department of bacteriology. There aerobic cultures are made on Oxoid No $27 \%$ horse-blood agar and on Oxoid cystine-lactose electrolytedeficient media, and anaerobic cultures are made on Oxoid No 2 blood agar with $100 \mathrm{mg} / \mathrm{l}$ of neomycin sulphate in evacuated containers with GasPak (BBL) hydrogen-carbon dioxide generators.

No firm guidelines were established for performing an incidental appendicectomy and the decision was made by the surgeon at the time of the operation. Wound sepsis was defined as the discharge of pus from the wound, and the few cases of secondary sepsis (associated with an intraperitoneal drain or a biliary leak) were excluded. Major sepsis was accompanied by constitutional disturbance and delayed the patient's discharge from hospital. Minor sepsis was more of a nuisance than anything else but caused inconvenience and worry to patients and family doctors.

The significances of differences were calculated by the $\chi^{2}$ test or Student's $t$ test as appropriate.

\section{Results}

The comparability of the two groups is shown in table I. Older people were significantly less likely than the young to have an incidental appendicectomy $\left(\chi^{2}=11.44 ; P<0.001\right)$, and when the gall bladder was inflamed or infected the appendix was significantly less likely to be removed than when the gall bladder was not inflamed $\left(\chi^{2}=19 \cdot 89\right.$; $P<0.001$ ). The distribution of obesity (defined as a thickness of subcutaneous fat of $2.5 \mathrm{~cm}$ or more, measured at operation, at the site of incision) was not significantly different between the two groups.

Forty-eight patients developed minor or major wound sepsis $(21.4 \%)$. The earliest day on which pus was discharged or evacuated was the second, and the latest the 18th. Fifteen of the 48 wounds $(31.2 \%)$ discharged pus on the eighth day or later and might have been missed in a retrospective analysis of case notes.

In patients protected by parenteral or intraincisional cephaloridine there were three cases of minor and two of major sepsis among 49 patients who underwent cholecystectomy alone $(10 \cdot 2 \%)$ compared with two cases of minor and two of major sepsis among 46 patients with incidental appendicectomy $(8.7 \%)$. In patients not protected by cephaloridine, however, there were four cases of minor and five of major sepsis among $56(16.1 \%)$ who had single operations compared with 30 (19 minor and 11 major) among $73(41 \cdot 1 \%)$ patients who had

TABLE I-Comparability of the two groups

\begin{tabular}{|c|c|c|c|}
\hline & $\begin{array}{l}\text { No }(\%) \text { who } \\
\text { underwent } \\
\text { cholecystectomy }\end{array}$ & $\begin{array}{c}\text { No (\%) who } \\
\text { underwent } \\
\text { cholecystectomy } \\
\text { plus } \\
\text { appendicectomy }\end{array}$ & $\begin{array}{c}\text { Total } \\
(=100 \%)\end{array}$ \\
\hline $\begin{array}{c}\text { Age: } \\
<30 \\
30-39 \\
40-49 \\
50-59 \\
60-69 \\
\geqslant 70\end{array}$ & $\begin{array}{r}6(37 \cdot 5) \\
13(46 \cdot 4) \\
7(26 \cdot 9) \\
12(31 \cdot 6) \\
41(51 \cdot 3) \\
26(72 \cdot 2)\end{array}$ & $\begin{array}{l}10(62 \cdot 5) \\
15(53 \cdot 6) \\
19(73 \cdot 1) \\
26(68 \cdot 4) \\
39(48 \cdot 8) \\
10(27 \cdot 8)\end{array}$ & $\begin{array}{l}16 \\
28 \\
26 \\
38 \\
80 \\
36\end{array}$ \\
\hline $\begin{array}{l}<60 \\
60^{*}\end{array}$ & $\begin{array}{l}38(35 \cdot 2) \\
67(57 \cdot 8)\end{array}$ & $\begin{array}{l}70(64 \cdot 8) \\
49(42 \cdot 2)\end{array}$ & $\begin{array}{l}108 \\
116\end{array}$ \\
\hline $\begin{array}{l}\text { State of gall bladder: } \\
\text { Inflamed or infected* } \\
\text { Not inflamed }\end{array}$ & $\begin{array}{l}39(73.6) \\
66(38.6)\end{array}$ & $\begin{array}{r}14(26 \cdot 4) \\
105(61 \cdot 4)\end{array}$ & $\begin{array}{r}53 \\
171\end{array}$ \\
\hline $\begin{array}{l}\text { Men } \\
\text { Women } \\
\text { Obese } \\
\text { Not obese }\end{array}$ & $\begin{array}{l}22(44.9) \\
83(47 \cdot 4) \\
50(43.9) \\
55(50 \cdot 0)\end{array}$ & $\begin{array}{l}27(55 \cdot 1) \\
92(52 \cdot 6) \\
64(56 \cdot 1) \\
55(50 \cdot 0)\end{array}$ & $\begin{array}{r}49 \\
175 \\
114 \\
110\end{array}$ \\
\hline
\end{tabular}

*There were significantly more patients over the age of 60 and with inflamed or infected gall bladders in the cholecystectomy-alone group. The other differences were nut significant. their appendix removed as well. This difference was significant $\left(\chi^{2}=9.41 ; \mathrm{P}<0.01\right)$ (table II).

In the absence of effective antibiotic prophylaxis obese patients were more liable to develop wound sepsis than others (table III). The sepsis rate in those who underwent cholecystectomy alone was $17.2 \%$ in the obese and $11.1 \%$ in the non-obese. The corresponding figures for those who had a cholecystectomy with appendicectomy were $53.8 \%$ and $26.5 \%$. The latter difference was significant $\left(\chi^{2}=\right.$ $5.62 ; \mathrm{P}<0.02)$.

When patients' ages were analysed against type of operation and antibiotic prophylaxis no significant differences were found. Twentyfive out of 108 patients under the age of $60(23.1 \%)$ developed wound sepsis compared with 23 out of 116 over this age $(19 \cdot 8 \%)$.

TABLE II-Wound sepsis rates

\begin{tabular}{|c|c|c|c|c|}
\hline & \multicolumn{2}{|c|}{$\begin{array}{l}\text { Cholecystectomy } \\
\text { alone }\end{array}$} & \multicolumn{2}{|c|}{$\begin{array}{l}\text { Cholecystectomy } \\
\text { and appendicectomy }\end{array}$} \\
\hline & $\begin{array}{c}\text { No of } \\
\text { patients }\end{array}$ & $\begin{array}{l}\text { No }(\%) \\
\text { with } \\
\text { wound } \\
\text { sepsis }\end{array}$ & $\begin{array}{c}\text { No of } \\
\text { patients }\end{array}$ & $\begin{array}{l}\text { No }(\%) \\
\text { with } \\
\text { wound } \\
\text { sepsis }\end{array}$ \\
\hline $\begin{array}{l}\text { Cephaloridine prophylaxis } \\
\text { Others: } \\
\text { No prophylaxis } \\
\text { Intraincisional gentamicin } \\
\text { Intraincisional povidone-iodine } \\
\text { Intraincisional framycetin } \\
\text { Intraincisional ampicillin } \\
\text { Water irrigation }\end{array}$ & $\begin{array}{l}49 \\
56 \\
17 \\
9 \\
8 \\
6 \\
15 \\
1\end{array}$ & $\begin{aligned} & 5(10 \cdot 2) \\
& 9(16 \cdot 1) \\
& 3(17 \cdot 6) \\
& 1(11 \cdot 1) \\
& 2(25 \cdot 0) \\
& 2(33 \cdot 3) \\
& 1(6 \cdot 7) \\
& 0(0)\end{aligned}$ & $\begin{array}{l}46 \\
73 \\
24 \\
14 \\
10 \\
5 \\
16 \\
4\end{array}$ & $\begin{array}{l}4(8 \cdot 7) \\
30(41 \cdot 1) \\
8(33 \cdot 3) \\
5(35 \cdot 7) \\
7(70 \cdot 0) \\
3(60 \cdot 0) \\
5(31 \cdot 3) \\
2(50 \cdot 0)\end{array}$ \\
\hline
\end{tabular}

TABLE III-Influence of obesity on wound sepsis rates in patients not protected by cephaloridine

\begin{tabular}{|c|c|c|c|c|c|}
\hline & \multicolumn{2}{|c|}{ Obese } & \multicolumn{2}{|c|}{ Not obese } & \multirow[b]{2}{*}{$\begin{array}{l}\text { Significance } \\
\text { of } \\
\text { difference } \\
\text { (P) }\end{array}$} \\
\hline & $\begin{array}{c}\text { No of } \\
\text { patients }\end{array}$ & $\begin{array}{l}\text { No }(\%) \\
\text { with } \\
\text { wound } \\
\text { sepsis }\end{array}$ & $\begin{array}{c}\text { No of } \\
\text { patients }\end{array}$ & $\begin{array}{c}\text { No }(\%) \\
\text { with } \\
\text { wound } \\
\text { sepsis }\end{array}$ & \\
\hline $\begin{array}{l}\text { Cholecystectomy alone } \\
\text { Cholecystectomy and } \\
\text { appendicectomy }\end{array}$ & $\begin{array}{l}29 \\
39\end{array}$ & $\begin{array}{r}5(17 \cdot 2) \\
21(53 \cdot 8)\end{array}$ & $\begin{array}{l}27 \\
34\end{array}$ & $\begin{array}{l}3(11 \cdot 1) \\
9(26 \cdot 5)\end{array}$ & $\begin{array}{c}\text { NS } \\
<0.02\end{array}$ \\
\hline Total & 68 & $26(38 \cdot 2)$ & 61 & $12(19 \cdot 7)$ & $<0.05$ \\
\hline
\end{tabular}

\section{BACTERIOLOGICAL STUDIES}

Swabs or fragments of 124 gall bladders, 46 appendices, and 51 subcutaneous tissues were examined bacteriologically. Eighty-six of the gall bladder cultures were sterile $(69.4 \%)$ compared with 13 $(28.3 \%)$ from the appendix and $37(72.5 \%)$ from subcutaneous tissue. The bacteria isolated are shown in table IV. Many cultures showed more than one organism, so the total number of organisms exceeded the total number of infected organs.

The sepsis rates correlated well with operative bacteriological findings (table V), being considerably higher when gall bladder or appendix, or both, were infected $\left(\chi^{2}=4 \cdot 71\right)$ and higher still when subcutaneous tissue was also infected $\left(\chi^{2}=4 \cdot 81\right)$. The differences were significant at the $5 \%$ level. Subcutaneous tissue was never infected when the organ culture was sterile.

TABLE IV-Results of operative bacteriology

\begin{tabular}{|c|c|c|c|}
\hline & Gall bladder & Appendix & $\begin{array}{c}\text { Subcutaneous } \\
\text { tissue }\end{array}$ \\
\hline $\begin{array}{l}\text { Swab or fragment sterile } \\
\text { Swab or fragment infected: } \\
\text { Escherichia coli } \\
\text { Streptococcus faecalis } \\
\text { Other streptococci } \\
\text { Clostridia } \mathrm{spp} \\
\text { Bacteroides } \mathrm{spp} \\
\text { Proteus } \mathrm{spp} \\
\text { Klebsiella } \mathrm{spp} \\
\text { Pseudomonas } \mathrm{spp} \\
\text { Enterobacter spp } \\
\text { Staplylococcus aureus } \\
\text { Staphylococcus epidermidis }\end{array}$ & $\begin{array}{rr} & 86 \\
24 & 38 \\
8 & \\
2 & \\
1 & \\
2 & \\
1 & \\
1 & \\
0 & \\
1 & \\
2 & \\
4 & \end{array}$ & $\begin{array}{rr} & 13 \\
31 & 33 \\
4 & \\
1 & \\
7 & \\
5 & \\
3 & \\
3 & \\
3 & \\
0 & \\
1 & \\
1 & \end{array}$ & $\begin{array}{ll} & 37 \\
& 14 \\
8 & \\
2 & \\
0 & \\
1 & \\
0 & \\
1 & \\
1 & \\
0 & \\
0 & \\
1 & \\
2 & \end{array}$ \\
\hline
\end{tabular}


TABLE V-Wound sepsis correlated with operative bacteriological findings

\begin{tabular}{|c|c|c|c|}
\hline & $\begin{array}{l}\text { Organ sterile, } \\
\text { subcutaneous } \\
\text { tissue sterile } \\
\text { or not taken }\end{array}$ & $\begin{array}{l}\text { Organ infected, } \\
\text { subcutaneous } \\
\text { tissue sterile } \\
\text { or not taken }\end{array}$ & $\begin{array}{c}\text { Organ and } \\
\text { subcutaneous } \\
\text { tissue infected }\end{array}$ \\
\hline $\begin{array}{l}\text { Number of cases } \\
\text { No }(\%) \text { of cases of wound sepsis }\end{array}$ & 61 & $\begin{array}{l}71 \\
17(23.9)\end{array}$ & 13 \\
\hline
\end{tabular}

OTHER SEPSIS

The incidence of sepsis in sites other than the wound was examined with particular reference to septicaemia, intraperitoneal abscesses, and serious chest complications. The single death from septic shock occurred after cholecystectomy alone, and there was one other case of septicaemia in this group and one after cholecystectomy and appendicectomy. Intraperitoneal abscesses developed in three patients after cholecystectomy alone and in four after cholecystectomy with appendicectomy. Serious chest infections occurred in 10 patients who had the single operation and in 11 who had an appendicectomy also. There was no significant difference in the incidence of any of these complications between the cholecystectomy group and those who had an appendicectomy as well.

Morbidity was also assessed by the number of days after operation that the patients spent in hospital. The mean number after cholecystectomy alone was $13 \cdot 13$ (SD 6.18) and after cholecystectomy plus appendicectomy 12.08 (SD 5.44). These means did not differ significantly $(t=1 \cdot 33)$. In many patients, particularly the elderly, discharge from hospital was delayed by social factors.

\section{Discussion}

Patients were not allocated to the groups randomly. The decision to take out the appendix was made by the operating surgeon and depended on factors such as his personal preference, the age of the patient, and the ease with which the gall bladder was removed. Occasionally a patient made a special request that the appendix should be removed, and this was normally granted. In no case was the incision extended to allow appendicectomy, and if the organ could not be delivered by gentle finger dissection the appendicectomy was abandoned.

We would have expected more wound sepsis after cholecystectomy alone, as more of the gall bladders in this group were inflamed. Over a third of the gall bladders removed without the appendix were inflamed or infected, compared with fewer than $12 \%$ of those accompanied by an incidental appendicectomy. The results, however, proved otherwise. When the wound was not protected by cephaloridine the sepsis rate when the appendix was removed incidentally was $41 \cdot 1 \%$ compared with $16 \cdot 1 \%$ when it was not removed.
The higher proportion of old people in the cholecystectomyalone group might be thought to be an additional hazard, ${ }^{9}$ although we have recently shown ${ }^{3}$ that old age alone has no importance as a cause of wound sepsis, and in this series the sepsis rate was slightly (but not significantly) lower in old people.

Norton et $a l^{10}$ compared the incidence of wound sepsis in patients undergoing a laparotomy for abdominal trauma with or without incidental appendicectomy and found a $7 \%$ incidence with and a $17 \%$ incidence without appendicectomy. They pointed out, however, that appendicectomy was much more likely to be performed when the laparotomy showed no serious intra-abdominal injury, and the series was therefore considerably biased. Komorn and Kaufman ${ }^{11}$ found that the addition of appendicectomy to cholecystectomy increased the wound sepsis rate, whereas Lowery and Lenhardt ${ }^{12}$ and Bogart and Sebesta ${ }^{13}$ did not confirm this.

All these studies suffer from the disadvantage of being retrospective, and the occurrence of wound sepsis (especially if it is late or minor) is often omitted from routine hospital notes. Our findings, based on prospective trials of methods of preverting surgical sepsis, showed that the addition of appendicectomy increases the risk of abdominal wall contamination and, in the absence of an effective antibiotic prophylactic regimen, the risk of sepsis.

We thank Dr K Froome and his staff in the department of bacteriology for their courtesy and co-operation at all times.

\section{References}

${ }^{1}$ Hewitt, D, Milner, J, and le Riche, W H, Canadian Medical Association fournal, 1969, 100, 1075.

${ }^{2}$ Howie, J G R, Scottish Medical fournal, 1968, 13, 72.

${ }^{3}$ Pollock, A V, Leaper, D J, and Evans, M, British fournal of Surgery, in press.

${ }^{4}$ Evans, C, and Pollock, A V, British fournal of Surgery, 1973, 60, 434.

5 Evans, C, Pollock, A V, and Rosenberg, I L, British fournal of Surgery, $1974,61,133$.

${ }^{6}$ Pollock, A V, and Rosenberg, I L, British Medical fournal, 1974, 2, 558.

7 Pollock, A V, and Evans, M, British fournal of Surgery, 1975, 62, 292.

8 Pollock, A V, and Evans, M, Fournal of Antimicrobial Chemotherapy, 1975, 1, Suppl, p 71 .

${ }^{9}$ Davidson, A I G, Clark, C, and Smith, G, British fournal of Surgery, $1971,58,333$.

10 Norton, L W, Sweeney, M, and Eiseman, B, British fournal of Surgery, $1975,62,487$.

11 Komorn, H, and Kaufman, L W, quoted by Norton et al. ${ }^{10}$

12 Lowery, C H, and Lenhardt, H F, Archives of Surgery, 1963, 85, 476.

13 Bogart, J N, and Sebesta, D G, American Surgeon, 1969, 35, 650.

(Accepted 21 October 1976)

\section{SHORT REPORTS}

\section{Relevance of race in management of testicular tumours}

Biopsy is usually regarded as contraindicated in cases of suspected malignancy of the testis because of the high risk of local recurrence and metastatic spread. ${ }^{1}$ Most such patients, therefore, are subjected to orchidectomy. ${ }^{2}$ Nevertheless, I suggest that limited biopsy should be used when the patient is from an ethnic group in which the prevalence of testicular cancer is low.

\section{Present series}

In a six-year period some 7500 surgical specimens from Nigerian Igbos were examined at a central laboratory. Of these, 21 were testicular samples -five biopsy specimens and 16 orchidectomy specimens-sent in by 16 doctors from 12 hospitals.

Of the five biopsy specimens, two appeared to be normal, and three showed evidence of Leydig-cell tumours, tuberculosis, and infarction respectively. Three of the 16 orchidectomy specimens were normal. Of the remainder, nine showed evidence of granulomatous orchitis-five idiopathic, two tuberculous, and two schistosomal; two embryonal carcinoma; one metastatic lymphoma; and one fibrous pseudotumour of the testicular tunic.

\section{Comment}

Only three of the 21 testicular samples in this series showed evidence of primary cancer, two being orchidectomy specimens. This reflects the low prevalance of testicular cancer in Negroes. ${ }^{134}$ Thus although $^{-1}$ orchidectomy is mandatory for patients whose ethnic origins indicate a high likelihood of testicular cancer, it should not be performed routinely on Negroes. Biopsy should be the rule. 